\title{
KEMISKINAN MASYARAKAT NELAYAN \\ DI DESA AENG BATU-BATU \\ KABUPATEN TAKALAR SULAWESI SELATAN
}

\section{POVERTY OF FISHERMAN SOCIETY IN AENG BATU-BATU VILLAGE TAKALAR DISTRICT SOUTH SULAWESI}

\author{
Tini Suryaningsi \\ Balai Pelestarian Nilai Budaya Makassar \\ Alamat Jalan Sultan Alauddin / Tala Salapang Km.7 Makassar \\ Telepon (0411) 885119, 883748, Faksimile (0411) 865166 \\ Pos-el:tea4_thinie@yahoo.com
}

Diterima 7 Juni 2017

Disetujui tanggal 17 November 2017

\begin{abstract}
This study aims to explain the poverty of fishing communities in the Aeng Batu-batu village, District of North Galesong, Takalar in 2016. The method used is qualitative method by interview, observation, and literature studies. The results showed that fishermen poverty caused by lack of attention from the government on the lives of the fishermen in the village of Aeng Batu-batu. Government programs have not touched all of the poor because of the lack of information about the culture of the people. This causes the only class of people who feel the government programs in order to alleviation poverty. In addition, fishing community in the village of Aeng Batu-batu has a cultural behavior which the circumstances that occurred in their lives is regarded as a destiny that can only be so defeatist. The fishing communities assume that in abundance gained an opportunity to meet their needs without setting aside pending earned income to sudden financial needs.
\end{abstract}

Keywords: poverty, fishing society, poor culture.

\begin{abstract}
ABSTRAK
Penelitian ini bertujuan untuk menjelaskan tentang kemiskinan pada masyarakat nelayan yang berada di Desa Aeng Batu-batu, Kecamatan Galesong Utara, Kabupaten Takalar tahun 2016. Metode yang digunakan adalah metode kualitatif dengan teknik wawancara, pengamatan, dan studi pustaka. Hasil penelitian menunjukkan bahwa kemiskinan nelayan disebabkan oleh kurangnya keberpihakan dari pemerintah terhadap kehidupan nelayan di Desa Aeng Batu-batu. Program pemerintah belum menyentuh seluruh lapisan masyarakat miskin karena kurangnya informasi tentang budaya masyarakatnya. Hal tersebut menyebabkan hanya segolongan masyarakat saja yang merasakan program pemerintah dalam rangka pengentasan kemiskinan. Selain itu, masyarakat nelayan di Desa Aeng Batu-batu memiliki budaya perilaku di mana keadaan yang terjadi dalam kehidupan mereka dianggap sebagai sebuah takdir sehingga hanya bisa bersikap pasrah. Masyarakat nelayan beranggapan bahwa rezeki yang banyak diperoleh merupakan suatu kesempatan untuk memenuhi kebutuhan mereka yang tertunda tanpa menyisihkan pendapatan yang diperoleh untuk kebutuhan yang sifatnya mendadak.
\end{abstract}

Kata kunci: kemiskinan, masyarakat nelayan, dan budaya miskin. 


\section{A. PENDAHULUAN}

Laut merupakan faktor lingkungan yang dalam banyak hal mempunyai pengaruh yang berarti dalam membangun citra budaya bangsa, termasuk di dalamnya berbagai satuan budaya suku bangsa dengan citra khasnya masing-masing. Laut di sekitar lahan hunian pasti mempunyai pengaruh tersendiri kepada orang dalam satuansatuan sosial yang tinggal di hunian yang bersangkutan. Pengaruh itu berada dalam berbagai ranah kehidupan (Sedyawati, 2014: 109). Dengan potensi yang besar, kesejahteraan bagi masyarakat di wilayah pesisir justru sangat minim dan identik dengan kemiskinan.

Masyarakat nelayan secara geografis adalah masyarakat yang hidup, tumbuh, dan berkembang di kawasan pesisir, yakni suatu kawasan transisi antara wilayah darat dan laut. Sebagai suatu sistem, masyarakat nelayan terdiri atas kategorikategori sosial yang membentuk kesatuan sosial. Menurut Sebenan, bahwa masyarakat di kawasan pesisir sebagian besar berprofesi sebagai nelayan yang diperoleh secara turun-temurun dari nenek moyang mereka (Sebenan dalam Wasak, 2012: 1339). Karakteristik masyarakat nelayan terbentuk mengikuti sifat dinamis sumber daya yang digarapnya, sehingga untuk mendapatkan hasil tangkapan yang maksimal, nelayan harus berpindah-pindah. Selain itu, risiko usaha yang tinggi menyebabkan masyarakat nelayan hidup dalam suasana alam yang keras, yang selalu diliputi ketidakpastian dalam menjalankan usahanya.

Menurut Imron, nelayan adalah suatu kelompok masyarakat yang kehidupannya tergantung langsung pada hasil laut, baik dengan cara melakukan penangkapan ataupun budidaya (Imron, 2003: 63). Mereka pada umumnya tinggal di pinggir pantai, seluruh lingkungan permukiman yang dekat dengan lokasi kegiatannya. Citra kemiskinan nelayan itu sesungguhnya suatu ironi, mengingat Indonesia memiliki wilayah laut yang sangat luas, lebih luas dari daratan. Di dalam wilayah laut juga terdapat berbagai sumber daya yang memiliki potensi ekonomi tinggi, yang semestinya dapat dimanfaatkan untuk menjamin kesejahteraan hidup nelayan dan keluarganya.

Ciri masyarakat nelayan menurut Husen dapat dilihat sebagai berikut, dari segi mata pencaharian, nelayan adalah mereka yang segala aktivitasnya berkaitan dengan lingkungan laut dan pesisir, atau mereka yang menjadikan perikanan sebagai mata pencaharian (Husen, 2014: 1). Dari segi cara hidup, masyarakat nelayan adalah masyarakat gotong-royong, kebutuhan gotong-royong atau tolong menolong terasa sangat penting untuk mengatasi keadaan yang menuntut pengeluaran biaya besar dan pengerahan tenaga yang banyak. Seperti saat berlayar, membangun rumah atau tanggul penahan gelombang di sekitar desa. Dari segi keterampilan, meskipun pekerjaan nelayan adalah pekerjaan berat namun pada umumnya mereka hanya memiliki keterampilan sederhana.Kebanyakan mereka bekerja sebagai nelayan adalah profesi yang diturunkan dari orang tua bukan yang dipelajari secara profesional.

Selain hal tersebut di atas, Kusnadi menjelaskan bahwa penggolongan sosial masyarakat nelayan dibagi ke dalam tiga sudut pandang, yaitu: dilihat dari segi penguasaan alat-alat produksi atau peralatan tangkap (perahu, jaring, dan perlengkapan lainnya), struktur masyarakat ini terbagi menjadi kategori nelayan pemilik (alat-alat produksi) dan nelayan buruh yang tidak memiliki alat-alat produksi dan dalam kegiatan produksi sebuah unit perahu, nelayan buruh hanya menyumbangkan jasa tenaganya dengan memeroleh hak-hak yang sangat terbatas (Kusnadi dalam Suyanto, 
2013: 53). Dari skala investasi modal usahanya, struktur masyarakat nelayan terbagi menjadi nelayan besar di mana jumlah modal yang diinvestasikan dalam hal perikanan relatif banyak, dan nelayan kecil justru sebaliknya. Dari tingkat teknologi peralatan tangkap ikan, yang terbagi menjadi nelayan modern yaitu nelayan yang menggunakan teknologi penangkapan yang lebih canggih dari nelayan tradisional. Perbedaan ini membawa implikasi pada tingkat pendapatan dan kemampuan atau kesejahteraan sosial-ekonomi. Di dalam stratifikasi yang ada dibandingkan nelayan pemilik, tingkat kehidupan sosial-ekonomi nelayan buruh sangat rendah dan bahkan dapat dikatakan sebagai lapisan sosial yang paling miskin di desa-desa pesisir.

Masalah utama yang dihadapi oleh masyarakat nelayan adalah kemiskinan yang perlu mendapat perhatian lebih khusus dan terfokus. Kemiskinan yang mereka alami merupakan suatu realita atau fakta yang tak terbantahkan. Fenomena kehidupan sosial masyarakat miskin di sekitar pesisir, khususnya kehidupan nelayan tradisional, sering diidentifikasi sebagai kehidupan kelompok masyarakat khusus yang selama ini kental dengan karateristik memiskinannya: tinggal di perkampungan kumuh, memiliki aspirasi dan akses yang rendah terhadap pelayanan sosial dasar seperti pendidikan dan kesehatan serta bantuan sosial lainnya. Kondisi kehidupan sosial seperti itu dapat disebut sebagai ketidakterjaminan sosial struktural (structural insecurity) yang antara lain disebabkan oleh tingkat pembangunan ekonomi yang tidak memadai (Pusat Penelitian Permasalahan Kesejahteraan Sosial \& Lembaga Penelitian Universitas Hasanuddin, 2005: 1).

Kemiskinan dalam kehidupan masyarakat pada umumnya dihubungkan dengan faktor ekonomi di mana ketidakmampuan dalam pemenuhan kebutuhan hidup dalam arti rendahnya penghasilan atau mata pen- caharian yang diterima dalam bekerja. Menurut Suyanto, ciri-ciri kemiskinan yaitu: 1) mereka yang hidup di bawah garis kemiskinan pada umumnya tidak memiliki faktor produksi sendiri, 2) pada umumnya tidak mempunyai kemungkinan untuk memeroleh aset produksi dengan kekuatan sendiri. Pendapatan tidak mencukupi untuk memeroleh modal usaha, 3) tingkat pendidikan golongan miskin umumnya rendah, tidak sampai tamat sekolah, 4) banyak di antara mereka yang tinggal di daerah pedesaan dan tidak memiliki tanah garapan, atau kalaupun ada relatif kecil sekali (Suyanto, 2013: 5). Sebagian besar hasil kajian akademis telah menempatkan masyarakat pesisir, khususnya masyarakat nelayan, sebagai masyarakat yang memiliki sejumlah keterbatasan sosial ekonomi, seperti keterbelakangan sosial, kemiskinan, dan tingkat kesejahteraan yang rendah. Hanya sebagian kecil masyarakat pesisir yang taraf kehidupannya di atas rata-rata, seperti pedagang perantara dan pemilik perahu yang sukses. Sangat jarang, bahkan sulit ditemukan adanya sebuah desa nelayan yang memiliki kemakmuran ekonomi secara merata (Kusnadi, 2013: 48).

Kemiskinan pada nelayan setidaknya dapat dikelompokkan menjadi tiga bentuk kemiskinan berdasarkan faktor pembentuknya. Pertama, kemiskinan struktural. Kemiskinan ini diderita oleh segolongan nelayan karena kondisi struktur sosial yang ada menjadikan mereka tidak dapat ikut menggunakan sumber-sumber pendapatan yang sebenarnya tersedia, juga akibat tatanan kebijakan yang lebih menguntungkan golongan pemilik modal (nelayan besar). Kekuatan-kekuatan di luar rumah tangga nelayan kecil menjadikan mereka terpinggirkan dan hidup dalam belenggu kemiskinan. Jadi persoalannya adalah ketidakmerataan akses pada sumberdaya karena struktur sosial yang ada. Kedua, kemiskinan kultural yang melihat kemiskinan terjadi 
karena faktor budaya seperti kemalasan yang bersumber pada nilai-nilai lokal yang memang tidak kondusif bagi suatu kemajuan. Kemiskinan ini tidak lepas dari tata nilai yang dianut rumah tangga nelayan yang bersangkutan dalam menjalani hidup. Ketiga, kemiskinan alamiah terjadi di mana kondisi alam yang tidak mendukung mereka melakukan kegiatan ekonomi produktif ataupun perilaku produksi yang tidak produktif akibat sifat sumber daya yang bersangkutan. Dalam konteks masyarakat nelayan, dapat digambarkan akibat laut dipandang sebagai common property dan akses terbuka menjadikan perikanan laut dieksploitasi secara berlebih bahkan dengan alat dan bahan terlarang. Para nelayan berperilaku untuk saling mendahului dan berupaya memeroleh hasil tangkapan lebih banyak dibanding nelayan lain. Bahkan sebagian dari mereka menggunakan alat atau bahan terlarang tanpa berfikir masalah keberlanjutan sumberdaya ikan yang ada (Tain, 2011: 3).

Banyak pendekatan yang digunakan untuk membahas tentang kemiskinan ini. Ada sebagian pihak membuat batasan bahwa taraf hidup di bawah garis kemiskinan dilihat dari kondisi gizi yang rendah, pendidikan yang serba memprihatinkan, perikehidupan yang dilingkari kemelaratan, yang sering mewarnai daaerah-daerah yang terkena bencana. Dalam dinamika pembangunan, di satu sisi memang telah terjadi bersamaan dengan itu juga terdapat penduduk miskin yang absolut. Kondisi ini merupakan indikator bahwa pendekatan nasional masih belum terdistribusi secara merata. Menurut Bank Dunia, proporsi pembagian pendapatan nasional di negara-negara berkembang senantiasa menunjukkan sebuah ketidakberimbangan antara warga miskin yang berjumlah besar dan warga kaya yang berjumlah lebih kecil. Selain itu, keberhasilan pembangunan yang berpedoman pada peningkatan pendapatan nasional yang dikaitkan dengan kesuksesan dalam mengentaskan kemiskinan lebih terjebak pada angka-angka statistik yang sama sekali tidak diikuti pula kenaikan pendapatan di sektor riil (Setiadi, 2011: 788).

Penanggulangan kemiskinan selama ini telah ditangani melalui berbagai kebijakan dan mekanisme, misalnya Bantuan Langsung Tunai (BLT), namun kurang efektif karena banyak yang salah sasaran, bahkan membuka peluang penyalahgunaan dana sehingga berakibat konflik sosial. Konsep kuantitatif dengan sistem pendataan penduduk miskin belum sepenuhnya menjangkau masyarakat sehingga pembangunan menjadi terhambat karena penyajian data yang selalu tidak akurat. Kenyataan yang terjadi adalah kebijakan negara mengakibatkan adanya kelompok masyarakat yang terjebak dalam kemiskinan. Kelompok miskin tidak dapat dijangkau dengan pendekatan kuantitatif namun harus secara keseluruhan dengan melihat dengan pendekatan kualitatif masyarakatnya berdasarkan pengetahuan lokal (Pattinama, 2009: 2).

Kelompok masyarakat yang selama ini menjadi fokus penelitian karena menyangkut kemiskinan adalah masyarakat nelayan. Keadaan masyarakat nelayan yang selalu diidentikkan dengan masalah kemiskinan perlu mendapat perhatian yang serius mengenai sebab-sebab yang membuat mereka dikatakan miskin. Bukan saja secara struktural, namun secara kultural juga memengaruhi kehidupan masyarakat nelayan sehingga dikondisikan sebagai masyarakat yang berada dibawah garis kemiskinan. Kondisi ini terjadi pula pada masyarakat nelayan yang bermukim di Desa Aeng Batu-Batu yang dikategorikan sebagai perkampungan nelayan miskin. Dari penjelasan tersebut yang menjadi permasalahan dalam penelitian ini adalah bagaimana kemiskinan pada masyarakat nelayan di Desa Aeng Batu-Batu Kecamatan Galesong Utara Kabupaten Takalar. Adapun 
tujuan penelitian ini yaitu untuk mengetahui kemiskinan pada masyarakat nelayan di Desa Aeng Batu-Batu Kecamatan Galesong Utara, Kabupaten Takalar. Kajian ini diharapkan dapat menambah pengetahuan sebagai bekal dalam mengaplikasikan pengetahuan teoritik terhadap masalah penelitian dan diharapkan dapat menjadi acuan bagi siapa saja, khususnya bagi pemerintahan dalam kebijakan penanggulangan kemiskinan bagi masyarakat nelayan.

Penelitian masalah kemiskinan nelayan diungkapkan pula oleh Arifin (2014) dalam bukunya mengenai perangkap kemiskinan dan kekerasan struktural bagi nelayan di Takalar berkenaan dengan relasi kerja pinggawa dan sawi. Namun hanya dikhususkan pada kemiskinan yang bersifat struktural saja. Sedangkan dalam tulisan ini menjelaskan tentang kemiskinan yang dilihat tidak hanya secara struktural saja namun juga dilihat secara kultural yaitu pengaruh budaya masyarakatnya sehingga mereka tidak bisa keluar dari lingkaran kemiskinan.

Penelitian ini dilaksanakan di Desa Aeng Batu-Batu, Kecamatan Galesong Utara, Kabupaten Takalar, Sulawesi Selatan, tahun 2016. Penelitian ini adalah penelitian yang bersifat deskriptif dengan memfokuskan pada penyebab terjadinya kemiskinan pada masyarakat nelayan di Desa Aeng BatuBatu baik secara struktural maupun kultural. Penyebab tersebut merupakan hal yang penting untuk diungkapkan secara deskriftif kualitatif. Metode penelitian yang digunakan adalah metode kualitatif. Metode ini diharapkan dapat mengungkap permasalahan yang berhubungan dengan penelitian ini. Penelitian difokuskan pada penyebab kemiskinan yang terjadi pada masyarakat nelayan. Data yang dikumpulkan berupa data primer dan data sekunder. Data primer berupa observasi dan wawancara. Observasi dilakukan pada saat terjadi aktivitas budaya dan wawancara secara mendalam (Endraswara, 2012:
208). Observasi dilakukan dengan melihat aktivitas masyarakat nelayan serta kondisi atau keadaan di lingkungan tempat tinggal mereka. Selain itu dilakukan pengamatan terhadap jenis perahu yang digunakan serta alat tangkapnya. Wawancara dilakukan di lingkungan tempat para nelayan tinggal, yakni informan yang mengetahui banyak tentang obyek penelitian. Wawancara dilakukan secara santai namun serius agar informasi yang diperoleh bisa mengalir dan mendapatkan data yang dibutuhkan. Sedangkan data sekunder berupa studi pustaka, melalui literatur yang telah ada untuk dijadikan tinjauan pustaka sebagai acuan penelitian ini. Pada penelitian ini, verifikasi data dilakukan secara terus menerus sepanjang proses penelitian dilakukan. Sejak pertama memasuki lapangan dan selama proses pengumpulan data, peneliti berusaha untuk menganalisis dan mencari makna dari data yang dikumpulkan. Pada akhirnya, data akan diinterpretasikan dalam kaitannya dengan materi penelitian. Hasil analisis data merupakan jawaban terhadap masalah yang dikemukakan dalam penelitian ini.

\section{B. HASIL DAN BAHASAN}

\section{Gambaran Umum Lokasi Penelitian}

Kabupaten Takalar secara astronomis terletak antara 5,3 - 5,38 Lintang Selatan dan 119,02 - 119,39 Bujur Timur mempunyai batas-batas wilayah, yaitu sebelah Utara berbatasan dengan Kotamadya Makassar dan Kabupaten Gowa, sebelah Timur berbatasan dengan Jeneponto dan Kabupaten Gowa, sebelah Selatan berbatasan dengan Laut Flores, dan sebelah Barat berbatasan dengan Selat Makassar. Ibukota Kabupaten Takalar adalah Pattallassang, terletak $29 \mathrm{~km}$ arah selatan dari kota Makassar Ibukota Propinsi Sulawesi Selatan. Luas wilayah Kabupaten Takalar adalah 566,51 $\mathrm{km}^{2}$, di mana 240,88 
$\mathrm{km}^{2}$ diantaranya merupakan wilayah pesisir dengan panjang garis pantai sekitar $74 \mathrm{~km}$.

Topologi wilayah Kabupaten Takalar terdiri dari daerah pantai, dataran dan perbukitan. Di bagian barat adalah daerah pantai dan dataran rendah dengan kemiringan antara $0-3$ derajat sedang ketinggian ruang bervariasi antara $0-25 \mathrm{~m}$, dengan bantuan penyusun geomorfologi dataran di dominasi endapan alluvial, endapan rawa pantai, batu gamping terumbu dan tufa serta beberapa tempat bantuan lelehan basal. Secara hidrologis Takalar beriklim tropis dengan dua musim, yaitu musim hujan dan musim kemarau. Musim hujan biasanya terjadi antara bulan November hingga bulan Mei. Rata-rata curah hujan bulanan pada musim hujan berkisar antara 11,7 mm hingga 653,6 $\mathrm{mm}$ dengan curah hujan tertinggi rata-rata harian adalah $27,9^{\circ} \mathrm{C}$ (Oktober) dan terendah $26,5^{\circ} \mathrm{C}$ (Januari - Februari). Temperatur udara terendah rata-rata 22,2 hingga $20,4^{\circ} \mathrm{C}$ pada bulan Februari - Agustus dan tertinggi $30,5-33,9^{\circ} \mathrm{C}$ pada bulan September - Januari.

Kabupaten Takalar dengan jumlah penduduk 240.578 jiwa mempuyai jumlah penduduk miskin sejumlah 50.912 jiwa, atau $21,16 \%$ dari jumlah penduduk. Jumlah penduduk miskin tersebut terbagi dalam 15.228 KK. Kecamatan Polongbangkeng Utara merupakan kecamatan yang mempunyai jumlah penduduk termiskin (16.625 jiwa) diikuti oleh Mangarabombang (13.525 jiwa), Galesong Utara (7.952 jiwa), Polongbangkeng Selatan (6.770 jiwa), Pattallasang (6.636 jiwa), dan terkecil pada Mappakasunggu (4.148 jiwa), (Kantor Desa Aeng Batu-Batu, 2015).

\section{Penyebab Kemiskinan}

Kemiskinan tidak akan terjadi begitu saja, akan tetapi memiliki asal-muasal ataupun penyebab-penyebab sehingga dikatakan miskin. Selain faktor yang sifatnya alami, seperti kondisi cuaca yang menyebabkan nelayan tidak dapat melaut, akan tetapi juga dipengaruhi oleh kebiasaan atau budaya dari masyarakatnya sendiri. Oleh sebab itu pentingnya untuk mengetahui penyebab dari kemiskinan yang ada di masyarakat nelayan khususnya yang terdapat di Desa Aeng Batu-Batu, Kecamatan Galesong Utara, Kabupaten Takalar. Kemiskinan pada masyarakat nelayan di Desa Aeng BatuBatu dapat diklasifikasikan menjadi dua, yaitu kemiskinan struktural dan kemiskinan kultural. Adapun penjelasan tentang kemiskinan tersebut adalah sebagai berikut:

\section{a. Kemiskinan Struktural}

Kemiskinan secara struktural merupakan jenis kemiskinan di mana terjadi karena tidak berfungsinya dengan baik sistem sosial yang bisa memberikan ruang dan kesempatan bagi masyarakat yang dikategorikan miskin untuk bisa mengembangkan diri sesuai dengan kemampuan yang dimiliki bahkan dengan jalan mempelajarinya. Ketidakmampuan mereka dalam mengelola sumber daya alam dikarenakan kurangnya dukungan dan sarana yang bisa menolong mereka lewat bantuan dan kebijakan yang menjadi harapan masyarakat miskin. Kemiskinan struktural bisa dikatakan disebabkan oleh berbagai kebijakan yang diberikan akan tetapi dalam pelaksanaannya tidak seimbang, kesempatan yang tidak sama serta keikutsertaan masyarakatnya dalam program kebijakan yang tidak merata. Beberapa penyebab kemiskinan secara struktural, diurai sebagai berikut :

\section{a.1 Perahu Bukan Milik Sendiri}

Kepemilikan perahu nelayan di Desa Aeng Batu-Batu hanya milik pemodal yang besar. Nelayan kecil hanya mampu membeli jala sendiri, sedangkan perahu masih meminjam karena keterbatasan modal untuk memiliki perahu sendiri. Oleh karena itu, untuk pembagian hasil harus dibagi dengan pemilik perahu.

Bantuan pemerintah yang diharapkan juga tidak nampak, sehingga nelayan hanya 
bisa mengusahakan jaring untuk dapat dipakai melaut. Nelayan berharap mereka mendapat bantuan berupa perahu sendiri agar mereka bisa memeroleh hasil yang tidak harus dibagi lagi kepada pemilik perahu tempat mereka meminjam. Karena hal tersebut merupakan salah satu kendala bagi masyarakat nelayan di Desa Aeng Batu-Batu untuk bisa mendapatkan hasil yang lebih banyak dan bisa memeroleh pendapatan yang lebih baik.

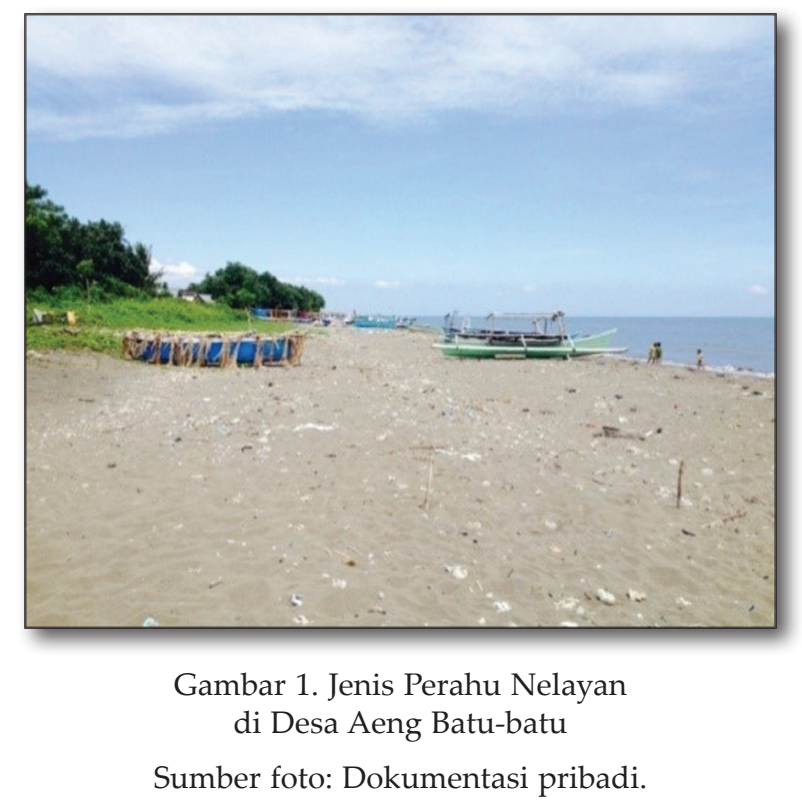

Pinjaman dengan bunga tinggi merupakan salah satu kendala bagi nelayan di Desa Aeng Batu-Batu untuk bisa memperbaiki kehidupannya sehari-hari. Nelayan di Desa Aeng Batu-Batu mengandalkan hidupnya di laut, akan tetapi tidak akan memenuhi kebutuhannya jika ada masalah dengan peralatan untuk digunakan dalam melaut. Seperti perbaikan jala, alat tangkap, yang dianggap sudah tua sangat sulit dilakukan karena masyarakatnya hanya bisa mengusahakannya sendiri. Seperti nelayan Parere yaitu nelayan sehari-hari, yang setiap harinya turun melaut hanya menangkap ikan yang kecil-kecil seperti tembang untuk hasil tangkapan mereka. Untuk kesemuanya itu diperlukan dana yang tidak sedikit agar peralatan melaut bisa digunakan lagi.
Koperasi yang biasanya ada pada kelompok nelayan, di Desa Aeng Batu-Batu sendiri tidak nampak. Hal tersebut menjadi sulit karena mereka akan berusaha mendapatkan pinjaman ke tempat lain. Pemerintah sebagai pemerhati masyarakat belum memberikan wadah yang dapat membantu para nelayan berkaitan dengan pinjaman sebagai modal dengan bunga yang sangat rendah. Keadaan tersebut seperti terabaikan dengan kurangnya bantuan diberikan kepada masyarkat nelayan di Desa Aeng Batu-Batu.

Menurut salah seorang nelayan H.Pa'bi (58 tahun), mengatakan bahwa bantuan pemerintah hanya berupa beras raskin saja, sedangkan itu pembagiannya tidak jelas, terkadang sebulan sekali, dua sampai tiga bulan juga baru mereka dapatkan. Keterbatasan yang ada menjadikan nelayan juga sulit keluar dari kehidupan yang kurang baik dan menguntungkan bagi mereka. Mereka masih mengandalkan pemodal besar dalam memenuhi kebutuhan hidup mereka.

Nelayan terkadang ingin beralih profesi menjadi pengusaha rumput laut akan tetapi mereka juga terkendala dengan modal yang banyak untuk mengusahakan lahan tempat berkembangbiaknya tanaman rumput laut seperti yang terdapat di desa tetangga. Karena hal tersebut, nelayan di Desa Aeng Batu-Batu terkadang memungut rumputrumput laut yang hanyut dari milik orang lain untuk menambah penghasilan dalam keluarga.

Kabupaten Takalar berdasarkan data BPS (Nahdyah, 2014: 82) menunjukkan sebaran perahu di wilayah mereka sebanyak 2.734 unit. Sebaran perahu tersebut terdapat di beberapa wilayah desa, yaitu perahu tanpa motor sebanyak 730 unit, yang terdiri dari 325 perahu jukung, 405 perahu papan. 1.379 unit perahu motor tempel, dan kapal motor 625 unit. 


\section{a.2 Kurangnya Hasil Tangkapan}

Karena penggunaan alat tangkap yang tradisional, nelayan pun hanya memeroleh hasil yang sangat sedikit setiap harinya. Untuk hasil tangkapan yang diperoleh setelah turun melaut, ada yang dipakai untuk konsumsi bagi keluarganya dan ada pula yang dijual.Jika hasil tangkapan sedikit, biasanya hanya dikonsumsi di rumah saja. Terkadang hasil tangkapan yang diperoleh langsung dijual kepada pengumpul ikan.

Hasil tangkapan, banyak maupun sedikit harus dilakukan pembagian dengan pinggawa mereka dengan sistem 90 banding 10. Yaitu pembagian hasil dengan sistem 90\% untuk pinggawa, dan 10\% untuk sawinya. Ketika sawi merapat ke pantai setelah melaut, maka mereka akan langsung menjual hasil tangkapan mereka ke tempat pelelangan ikan. Tempat pelelangan ikan tempat mereka menjual hasil tangkapan yaitu di Beba. Jika hasil tangkapan sudah di jual di Tempat Pelelangan Ikan (TPI) maka dilakukan pembagian kepada Pinggawa dan Sawi. Jika hasil tangkapan dalam sehari adalah Rp.1.000.000; maka pinggawa akan mendapatkan $90 \%$ dari hasil tangkapan maka pinggawa akan mendapatkan Rp. 900.000; karena pinggawa yang pemilik perahu, dan yang menyediakan bahan bakar dan alat tangkap. Sedangkan sawi hanya mendapat $10 \%$, atau sisanya dari perolehan pinggawa. Sawi yang terdiri dari beberapa orang harus dibagi dalam hasil $10 \%$ tersebut tidak mencukupi maka nelayan/sawi akan menggantungkan hidupnya kepada pemilik modal atau pinggawa. Oleh sebab itu terjadi relasi atau hubungan sosial di mana pinggawa dianggap sebagai dewa penyelamat bagi sawinya ketika mereka sangat membutuhkan bantuan keuangan, seperti keperluan berobat apabila anggota keluarga mereka sakit, membantu dalam membangun rumah, atau memberi pinjaman tanpa bunga, dan dibayarkan melalui pe- motongan pendapatan yang diperoleh selama melaut. Oleh sebab itu relasi yang terjalin antara pinggawa dan sawi sangat erat karena pinggawa dianggap sebagai penolong mereka ketika mereka sangat membutuhkan uang. Dan sawi akan merasa berutang budi atas kebaikan pinggawa walaupun memang mereka akan membayar lewat potongan dari pendapatan yang mereka peroleh. Oleh sebab itu terkadang uang hasil tangkapan ditambah dengan potongan dari pinggawa menyebabkan nelayan merasa pas-pasan dalam memenuhi kebutuhannya.

\section{a.3 Kurangnya Keberpihakan dari Pemerintah}

Salah satu harapan masyarakat dalam mengatasi kesulitan hidupnya adalah dari pemerintah sebagai pihak yang bertanggung jawab atas kesejahteraan rakyat. Melalui kebijakan dari pemerintah, masyarakat berharap bisa memperbaiki hidupnya ke arah yang lebih baik dari kehidupan sebelumnya baik melalui program pembangunan infrastruktur maupun bantuan pangan dan modal usaha.

Nelayan sebenarnya setempat memiliki keinginan untuk memiliki modal usaha sendiri. Rasa takut dan tidak berani untuk meminjam modal pada orang lain atau pada pinggawa dalam jumlah yang besar dikarenakan bunga yang tinggi, menyebabkan nelayan tidak mau mengambil resiko. Oleh karena sikap yang demikian menjadikan salah satu penyebab nelayan di Desa Aeng Batu-Batu pasrah dengan nasib dan rasa menerima keadaan yang ada. 


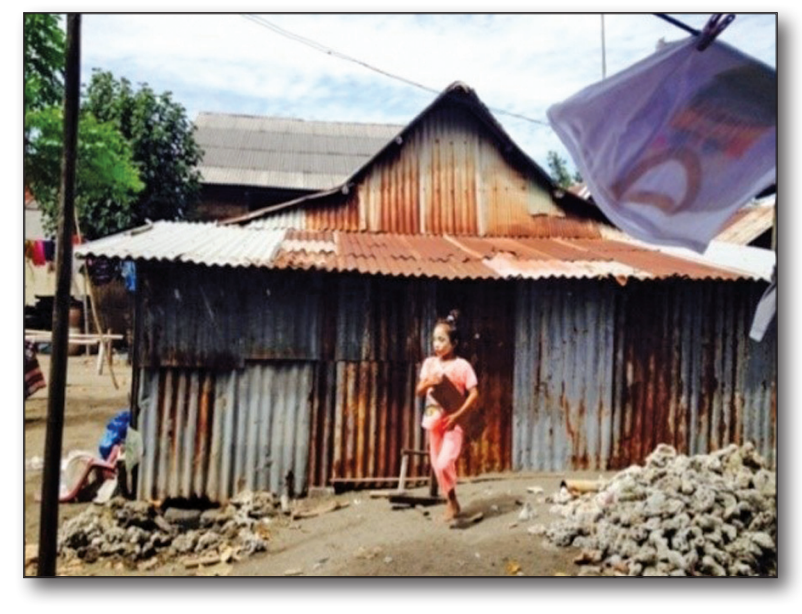

Gambar 2. Kondisi bagunan nelayan di Aeng Batu-batu

Sumber foto: Dokumentasi pribadi.

Bantuan pemerintah masih berfokus pada sarana umum dan infrastruktur desa. Seperti pembangunan sekolah dasar, mesjid, kantor desa, jalan desa, jembatan, sarana air bersih, puskesmas pembantu. Untuk pembangunannya, dilakukan secara gotongroyong oleh seluruh masyarakat setempat. Secara struktural, kemiskinan yang terjadi pada masyarakat nelayan di desa Aeng Batu-Batu merupakan tanggung jawab dari pemerintah selaku pemegang kekuasaan. Pemerintah berperan penting untuk bisa untuk mensejahterakan masyarakatnya melalui kebijakan yang berorientasi pada masyarakat miskin dalam pembangunan kesejahteraan secara menyeluruh.

Banyak program yang telah dilakukan oleh pemerintah dalam menanggulangi kemiskinan pada masyarakat akan tetapi sampai sekarang belum bisa mengangkat ekonomi masyarakat miskin secara menyeluruh. Bisa dikatakan program-program pemerintah belum berhasil mensejahterakan masyarakatnya. Karena kebijakan yang diberikan bersifat seragam pada seluruh lapisan masyarakat miskin, sehingga kebijakan yang diberikan tidak optimal karena permasalahan yang dihadapi oleh masyarakat lebih kompleks, tidak hanya permasalahan teknis semata tetapi lebih dilihat secara holistik. Perlunya perhatian yang menyeluruh dalam menyikapi setiap kebijakan yang diberikan apakah sudah tepat sasaran dan sesuai dengan harapan dari masyarakat.

Berdasarkan data dari Dinas Perikanan Kabupaten Takalar 2015, peran pemerintah terhadap nelayan di Takalar yaitu dengan memberikan bantuan berupa sarana dan prasarana perikanan, peningkatan kualitas sumber daya manusia khususnya nelayan melalui kegiatan pendidikan, pelatihan, dan penyuluhan.

Program pengentasan kemiskinan dinilai oleh masyarakat hanya bersifat instan saja karena hasil yang diperoleh hanya dinikmati sesaat saja. Seperti bantuan raskin yang hanya bisa dinikmati sesaat saja karena jika beras telah habis mereka akan merasa berat lagi dalam memenuhi kebutuhan hidup mereka. Hal ini membuktikan bahwa program yang digulirkan belum efektif di masyarakat. Keinginan masyarakat nelayan bertumpu pada bantuan modal yang bisa dipakai sebagai modal usaha.

Masalah raskin yang belum bisa memenuhi harapan masyarakat di Desa Aeng batuBatu menjadi kendala bagi masyarakat untuk bisa memenuhi kebutuhan hidupnya apalagi jika terjadi musim paceklik yaitu musim di mana nelayan terkadang tidak melaut karena cuaca yang tidak bersahabat. Program raskin menurut masyarakat terkadang tersendatsendat dan pembagiannya yang harus mendapat potongan sehingga dalam tiga bulan baru mendapat raskin dengan hanya diperoleh 15 - 20 kilo.

\section{b. Kemiskinan Kultural}

Permasalahan kemiskinan merupakan permasalahan yang tidak dilihat sematamata hanya menyangkut besaran ekonomi tetapi harus dilihat secara menyeluruh, yaitu dengan mempertimbangkan faktor budaya yang melekat pada masyarakat setempat yang justru menyebabkan mereka menjadi 
miskin karena budaya yang memengaruhi gaya berkehidupan mereka.

Kemiskinan kultural merupakan kemiskinan yang muncul akibat adanya nilai-nilai, kebiasaan, sikap atau tindakan yang dianut olehorang-orang miskin seperti malas, mudah menyerah pada nasib, kurang memiliki etos kerja. Ciri dari kebudayaan kemiskinan ini adalah enggan mengintegrasikan dirinya dalam lembaga-lembaga utama, sikap apatis, curiga, terdiskriminasi oleh masyarakat luas. Kebudayaan kemiskinan biasanya merupakan efek domino dari belenggu kemiskinan struktural yang menghinggapi masyarakat terlalu lama sehingga membuat masyarakat apatis, pasrah, berpandangan jika sesuatu yang terjadi adalah takdir dari Tuhan.

Laut adalah sumber kehidupan masyarakat Nelayan Desa Aeng Batu-Batu. Mata pencaharian utama mereka adalah nelayan Oleh karena itu masyarakat setempat tidak dapat terpisahkan dari kehidupan kemaritiman. Karena kehidupan mereka yang turun-temurun adalah nelayan, menyebabkan mereka hanya berfokus pada sektor kelautan. Tidak adanya keinginan untuk mencoba suatu kegiatan yang lain di luar sektor kelautan sebagai bentuk perubahan nasib kearah yang lebih baik. Berikut penyebab kemiskinan secara kultural:

\section{b.1 Pola Hidup Konsumtif}

Pengertian konsumtif ialah keinginan untuk mengkonsumsi barang-barang yang sebenarnya kurang diperlukan secara berlebihan untuk mencapai kepuasan yang maksimal. Konsumtif merujuk pada perilaku konsumen yang memanfaatkan nilai uang lebih besar dari nilai produksinya untuk barang dan jasa yang bukan menjadi kebutuhan pokok.

Hasil penelitian yang telah dilakukan menunjukkan bahwa nelayan di desa Aeng Batu-Batu memiliki pola hidup yang konsumtif. Hal ini dapat kita lihat dari uang hasil tangkapan mereka habis pada saat itu juga karena untuk memenuhi kebutuhan hidup mereka sehari-hari. Menurut Pak Lallo, nelayan (55 tahun),

“doe na gappayya takkulei na boli, ka jai inji parrallo na balli iyya'na passambung tallasa".

Artinya:

Uang yang diperoleh tidak dapat disimpan, karena masih banyak keperluan yang ingin dibeli, sebagai penyambung hidup.

Jika hasil tangkapan hari ini banyak, maka uangnya akan dipakai untuk membeli kebutuhan yang tidak sempat dibeli seperti panci, pakaian, ember, piring, dan peralatan lainnya yang termasuk dalam kebutuhan sekunder. Karena mereka berpikir kapan lagi bisa membeli apa yang diinginkan jika kebetulan ada uang. Seperti penuturan Ibu Tima (45 tahun):

"kalau suami dapat banyak rejeki karena tangkapannya banyak, bisa dipakai uangnya untuk beli baju sama celana di pasar, kebetulan lagi ada uang..."

Mereka juga mempersiapkan diri dengan membeli persiapan jika nelayan tidak pergi melaut akibat cuaca buruk atau sakit. Karena pengalaman mereka setiap tahunnya harus menghadapi musim paceklik, maka mereka hanya bisa mempersiapkan diri dengan membeli beberapa sembako untuk di simpan sebagai makanan pokok.

Uang hasil penjualan ikanjuga digunakan untuk membeli minuman keras (miras) yang bertujuan untuk menghangatkan badan di waktu malam. Biasanya para nelayan minum bersama-sama dengan mengumpulkan uang dari tiap-tiap nelayan yang memiliki uang, kemudian miras dibeli di pasar atau toko-toko di kota. Kebiasaan mengkonsumsi minuman keras sangat memengaruhi pendapatan nelayan. Uang hasil kerjanya hari itu juga dipakai untuk minum bersama nelayan yang 
lain. Kebiasaan tersebut menurut nelayan setempat sebagai bentuk kesetiakawanan dan kekeluargaan antar nelayan. Sambil minum, para nelayan akan bercerita tentang pengalaman mereka melaut.

Ditinjau dari segi ekonomi, kebiasaan mengkonsumsi minuman beralkohol termasuk dalam kebiasaan hidup boros. Dengan pendapatan setiap hari yang minim, mereka menyisipkan uangnya untuk membeli minuman tanpa berpikir untuk menyimpan uang tersebut untuk kebutuhan lainnya yang tidak terduga. Pak Duni (58 tahun) mengatakan:

"Panggappanna anne alloa, ni pakei allo annea tong, ammuko kulleji ni boya ammotere". Artinya:

Penghasilan hari ini digunakan hari ini juga, besok bisa dicari kembali.

Kutipan di atas, bagaimana nelayan menggunakan pendapatan mereka tiap harinya, penghasilan yang di peroleh hari ini adalah untuk memenuhi kebutuhan hari ini juga. Pemikiran yang seperti itu sangat berpengaruh dalam pemenuhan kebutuhan hidup yang serba kekurangan. Jika ada kebutuhan yang mendesak, nelayan meminjam uang kepada pinggawa.

Padahal jika dicermati, nelayan di Desa Aeng Batu-Batu memiliki etos kerja yang baik, karena mereka pergi melaut di waktu subuh dan pulang di waktu sore. Perlu adanya perubahan pandangan dari masyarakat nelayan dalam hal pengelolaan keuangan yang bisa dikondisikan di waktu normal ataupun di waktu paceklik. Dengan pengalaman bertahun-tahun dalam menghadapi musim paceklik, mereka harus bisa mengelola keuangan dengan sebaikbaiknya agar bisa tetap bertahan hidup.

\section{b.2 Sikap Pasrah Pada Keadaan}

Nelayan di Desa Aeng Batu-Batu hidupnya bergantung kepada laut. Sehingga rejeki mereka semuanya ditentukan oleh laut. Oleh karena kehidupan mereka sangat akrab dengan laut, membuat mereka sangat mengandalkan laut dalam memenuhi segala kebutuhan mereka. Kecintaan mereka akan dunia kemaritiman menyebabkan mereka enggan untuk berpikir bekerja di sektor lain di luar sektor kelautan. Seperti penjelasan berikut Aco (28 tahun), nelayan, menuturkan:

"Sangat susah untuk bisa beralih
pekerjaan selain sebagai nelayan karena
dari kecil sudah dididik secara turun
temurun hidup dengan laut dan susah
beralih ke usaha di darat karena tidak
ada pengetahuan dan keterampilan untuk
pekerjaan di darat"

Kendala yang dihadapi adalah tidak selamanya laut akan memberikan kehidupan bagi nelayan. Banyak halangan dan rintangan yang harus dihadapi oleh nelayan untuk bisa menikmati setiap hasil dari laut. Seperti kendala cuaca yang tidak menentu ataupun kondisi di mana laut tidak memberikan hasil. Dengan kondisi laut yang kadang tidak berpihak kepada nelayan, menyebabkan para nelayan hanya bisa pasrah dengan keadaan yang ada. Mereka hanya bisa menunggu hingga cuaca bisa kembali bersahabat bagi mereka untuk bisa kembali menangkap ikan. Ataupun jika hasil tangkapan yang diperoleh sangat sedikit atau bahkan tidak ada sama sekali, mereka hanya bisa menerima sebagai takdir di mana rejeki hari ini tidak ada. Seperti penuturan Diman (27 tahun), nelayan :

"kami hanya bisa pasrah kalau cuaca
lagi buruk, karena kami tidak bisa juga
memaksakan diri untuk pergi melaut
karena sangat berbahaya bagi keselamatan
kami. Yang ada hanya menunggu hingga
cuaca baik kembali walaupun sampai
seminggu tidak turun menangkap ikan"

Pernyataan tersebut di atas menunjukkan tidak adanya upaya lain yang bisa dilakukan oleh nelayan selama cuaca tidak bersahabat. Mereka hanya bisa menanti hingga cuaca bersahabat kembali agar mereka bisa kembali 
melaut. Nelayan menyadari bahwa untuk bisa merubah nasib atau memperbaiki hidup kearah yang lebih baik tidaklah semudah membalikkan telapak tangan. Kemiskinan yang terjadi pada nelayan dipengaruhi oleh latar belakang pendidikan yang rendah, keterampilan yang sangat terbatas, tidak adanya modal usaha, yang pada akhirnya mereka berpikir secara realistis dengan pasrah menerima keadaan dan hanya bisa berpikir bagaimana caranya agar tetap bertahan hidup daripada berpikir bagaimana memperbaiki taraf hidup mereka.

\section{b.3 Rendahnya Teknologi Penangkapan Ikan}

Penggunaan alat tangkap sangat memengaruhi nelayan dalam memeroleh hasil tangkapan. Alat tangkap yang masih tradisional dan sederhana, maka hasil tangkapan yang diperoleh tentu jauh berbeda dengan penggunaan alat tangkap yang lebih modern. Nelayan di desa Aeng Batu-Batu merupakan nelayan yang masih banyak menggunakan alat tangkap tradisional. Mereka masih menggunakan pancing dan jaring untuk menangkap ikan di laut. Hal tersebut memengaruhi hasil tangkapan nelayan sehari-hari. Jika hasil tangkapan sedikit maka akan memengaruhi pendapatan dalam keluarga sehingga kebutuhan hidup sulit untuk terpenuhi dengan baik.

Kebanyakan nelayan juga masih menggunakan perahu yang masih bersifat tradisional. Ada yang sudah menggunakan mesin dan ada juga yang belum menggunakan mesin. Jika mereka menggunakan perahu tanpa mesin maka tempat menangkap ikannya tidak terlalu jauh dari tempat tinggal mereka. Tapi jika memakai perahu dengan menggunakan mesin maka tempat penangkapan relatif jauh. Hal ini juga didukung oleh faktor alam yaitu cuaca.

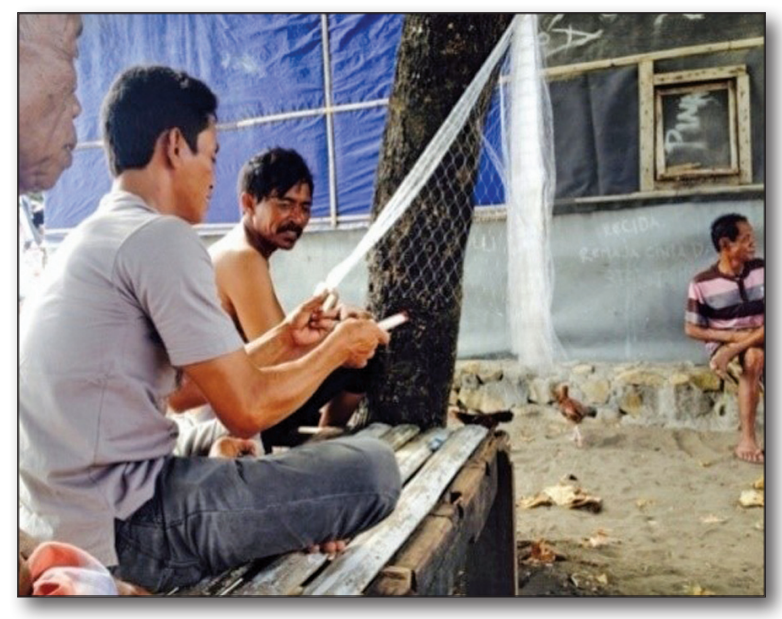

Gambar 3. Nelayan Aeng Batu-Batu sedang memperbaiki jaringnya.

Sumber foto: Dokumentasi pribadi.

Nelayan di Desa Aeng Batu-Batu adalah nelayan tradisional, maka sulit bagi mereka untuk mendapatkan alat-alat tangkap yang lebih modern dan perahu bermesin karena ketidakmampuan mereka untuk mendapatkan uang agar bisa mengganti alat tangkap mereka yang lebih modern. Mereka sangat berharap adanya bantuan dari pemerintah agar mereka bisa menggunakan alat tangkap yang bisa menghasilkan ikan lebih banyak sehingga ekonomi mereka bisa lebih baik.

Rendahnya teknologi penangkapan ikan juga disebabkan oleh kurangnya sumber daya manusia yang terampil dan memiliki kemampuan yang dibutuhkan untuk meningkatkan hasil dalam menangkap ikan. Hal ini disebabkan oleh rendahnya tingkat pendidikan yang dimiliki nelayan di desa tersebut. Hal ini dikarenakan tujuan utama mereka hidup adalah mencari makan lewat sumber laut maka hal dalam bidang pendidikan sedikit terabaikan oleh nelayan.

\section{PENUTUP}

Penyebab kemiskinan yang dialami oleh masyarakat nelayan di Desa Aeng Batu-Batu terbagi atas dua ketegori yaitu kemiskinan struktural dan kemiskinan kultural. Kemiskinan struktural bisa dikatakan disebabkan 
oleh berbagai kebijakan yang diberikan akan tetapi dalam pelaksanaannya tidak seimbang, kesempatan yang tidak sama serta keikutsertaan masyarakatnya dalam program kebijakan yang tidak merata. Kegiatan penanggulangan kemiskinan yang dilakukan pemerintah melalui berbagai program belum mampu mengeluarkan masyarakat nelayan dari keterpurukan ekonomi. Berbagai program penanggulangan kemiskinan yang telah dilakukan di Desa Aeng Batu-Batu sedikit dapat meringankan beban hidup masyarakat misal pembangunan pemukiman, sarana air bersih dan berbagai infrastruktur yang memberi kemudahan masyarakat nelayan dalam beraktivitas. Pemberian bantuan melalui dana bergulir, bantuan raskin dan kesehatan gratis belum menyentuh keseluruhan dari masyarakat. Bantuan ini sifatnya instan dan tidak efektif sehingga menjadikan ketergantungan yang membuat mereka selalu berharap, bukan memberi motivasi bagi dalam berusaha untuk lebih giat.

Kemiskinan kultural merupakan kemiskinan yang muncul akibat adanya nilainilai, kebiasaan, sikap atau tindakan yang dianut oleh orang-orang miskin seperti malas, mudah menyerah pada nasib, kurang memiliki etos kerja. Ada beberapa faktor penyebab kemiskinan pada masyarakat nelayan di Desa Aeng Batu-Batu di antaranya adalah faktor pendidikan, masyarakat nelayan di desa ini belum memiliki pendidikan yang layak. Tingkat pendidikan yang sangat rendah, masyarakat nelayan di Desa Aeng Batu-Batu belum tersentuh oleh teknologi yang modern karena ketidaktahuan mereka untuk memanfaatkan teknologi yang bisa membantu mereka untuk memeroleh hasil yang lebih baik. Pendapatan yang rendah menyebabkan keluarga nelayan tidak bisa hidup jauh dari batas kemiskinan dan tidak mampu mengembangkan dirinya. Dengan pendapatan yang rendah menyebabkan mereka tidak bisa menyisihkan pendapatannya untuk situasi yang mendadak atau musibah yang menimpa dan harus segera diatasi. Faktor infrastruktur, untuk sarana infrastruktur bisa dikatakan masih sangat minim di Desa Aeng BatuBatu.

Penyebab awal kemiskinan adalah faktor budaya masyarakat yang bersikap pasrah akan keadaan dan boros ketika memiliki rejeki dari hasil melaut. Budaya tersebut menyebabkan kurangnya keinginan untuk merubah perilaku yang menyebabkan mereka menjadi tidak bisa mengatur keuangan dengan baik apalagi untuk keadaan yang tidak dapat diprediksi. Kemudian pemerintah melihat situasi tersebut dengan memberikan program bantuan yang juga belum tepat sasaran sehingga kemiskinan nelayan sampai saat ini belum bisa dapat ditanggulangi dengan semestinya.

\section{DAFTAR SUMBER}

Arifin, Ansar. 2014. Perangkap Kemiskinan dan Kekerasan Stuktural di Balik Relasi Kerja Pinggawa Sawi. Jakarta: Orbit.

Endraswara, Suwardi. 2012. Metode Penelitian Kebudayaan. Yogyakarta: Gadjah Mada University Press.

Husen, Ishak S. 2014. "Dinamika Perubahan Sosial Masyarakat Nelayan dalam Peningkatan Taraf Hidup di Kelurahan Mafututu, Kota Tidore Kepulauan" Jurnal Holistik diunduh dari ejournal.unsrat.ac.id.

Imron, Mayuri. 2003. Kemiskinan dalam Masyarakat Nelayan.

Jurnal Masyarakat dan Budaya 5 (1), hlm: 63-82.

Kusnadi. 2013. Membela Nelayan. Yogyakarta: Graha Ilmu.

Pattinama, Marcus J. 2009. Pengentasan Kemiskinan dengan Kearifan Lokal (Studi Kasus di Pulau Buru-Maluku 
dan Surade Jawa Barat). Jurnal Makara, Sosial Humaniora". Volume 13 (1), hlm. 1-12.

Pusat Penelitian Permasalahan Kesejahteraan Sosial \& Lembaga Penelitian Universitas Hasanuddin. Kajian Sekuritas Sosial bagi Keluarga Nelayan Miskin di Kota Parepare Provinsi Sulawesi Selatan, Kota Baubau Provinsi Sulawesi Tenggara, dan Kotamadya Ternate Provinsi Maluku Utara. 2005.

Sedyawati, Elly. 2014. Kebudayaan di Nusantara, Dari Keris, Tor-tor, sampai Industri Budaya. Depok: Komunitas Bambu.

Setiadi, Elly \& Usman Kolip. 2011. Pengantar Sosiologi. Jakarta: Kencana.

Suyanto, Bagong. 2013. Anatomi Kemiskinan dan Strategi Penanganannya. Malang: In-TRANS Publishing.
Tain, Anas. 2011. Penyebab Kemiskinan Rumah Tangga Nelayan di Wilayah Tangkap Lebih Jawa Timur. Jurnal Humanity. Volume 7 (1), hlm. 1-10.

Wasak, Martha. 2012. Keadaan SosialEkonomi Masyarakat Nelayan di Desa Kinabuhutan, Kecamatan Likupang Barat, Kabupaten Minahasa Utara, Sulawesi Utara. Pasific Journal. Vol. 1 (7), hlm. 1339-1342.

Wawancara Aco, 28 tahun, Aeng Batu-Batu, 3 Mei 2015.

Wawancara Diman, 27 tahun, Aeng BatuBatu, 4 Mei 2015.

Wawancara Duni, 28 tahun, Aeng Batu-Batu, 10 Mei 2015

Wawancara H. Pa'bi, 58 tahun, Aeng BatuBatu, 7 Mei 2015.

Wawancara Lallo, 55 tahun, Aeng Batu-Batu, 10 Mei 2015. 